\title{
RADIATION HAZARDS ENCOUNTERED IN ARC MELTING THORIUM
}

By R. R. Lowery

* * * * * * * * * report of investigations 5969

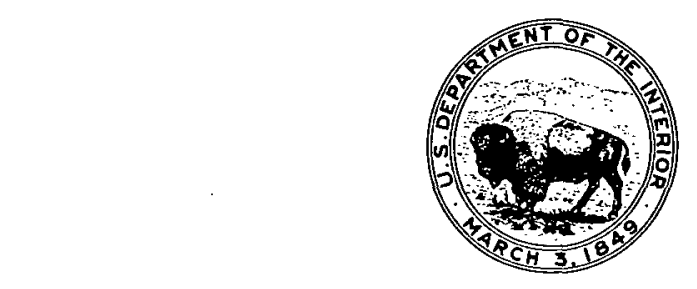

UNITED STATES DEPARTMENT OF THE INTERIOR

Stewart L. Udall, Secretary

BUREAU OF MINES

Marling J. Ankeny, Director

The work upon which this report is based was done under a cooperative agreement between the Bureau of Mines, U.S. Department of the Interior, and the Chicago Operations Office of the Atomic Energy Commission.

$$
442 \quad 002
$$




\section{DISCLAIMER}

This report was prepared as an account of work sponsored by an agency of the United States Government. Neither the United States Government nor any agency Thereof, nor any of their employees, makes any warranty, express or implied, or assumes any legal liability or responsibility for the accuracy, completeness, or usefulness of any information, apparatus, product, or process disclosed, or represents that its use would not infringe privately owned rights. Reference herein to any specific commercial product, process, or service by trade name, trademark, manufacturer, or otherwise does not necessarily constitute or imply its endorsement, recommendation, or favoring by the United States Government or any agency thereof. The views and opinions of authors expressed herein do not necessarily state or reflect those of the United States Government or any agency thereof. 


\section{DISCLAIMER}

Portions of this document may be illegible in electronic image products. Images are produced from the best available original document. 
This publication has been cataloged as follows:

\section{Lowery, Ronald R}

Radiation hazards encountered in arc melting thorium. [Washington] U.S. Dept. of the Interior, Bureau of Mines [1962]

22 p. illus., tables. $27 \mathrm{~cm}$. (U. S. Bureau of Mines. Report of investigations, 5969)

Bibliography: p. 21-22

Based on work done in cooperation with the Chicago Operations Office of the Atomic Energy Commission.

1. Thorium. 2. Radiation-Safety measures. I. Title. II. Title: Arc melting thorium.

TN23.U7 no. $5969 \quad 622.06173$

U. S. Dept. of the Int. Library

$442 \quad 003$ 
Summary ..................................... 1

Introduction .................................... 1

Thorium decay series ........................ 2

Radiotoxicity of thorium.................... 3

Thorium metallurgical processes................. 4

Arc melting.......................... 4

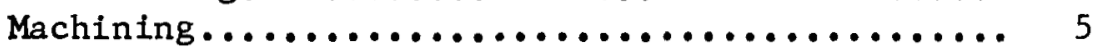

Forging ........................... 5

Acknowledgments .............................. 5

Experimental procedure and results................. 6

Breathing zone air sampling.................. 6

Analysis by absorption and decay............ 6

Pulse-height analysis.................... 9

Furnace residue sampling...................... 12

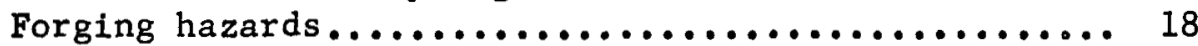

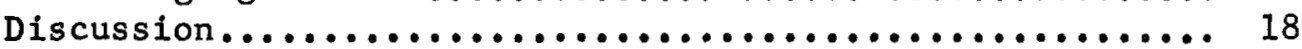

Bibliography ............................... 21

\section{ILLUSTRAT IONS}

Fige

1. The thorium decay series..................... 2

2. Consumable-electrode arc furnace............... 5

3. Typical alpha spectrum of short lived thorium chain isotopes.......................... 10

4. Alpha spectrum of air sample from unloading of furnace............................... 11

5. Alpha spectrum of air sample from ingot knockout.... 11

6. Alpha spectrum of air sample from machining of

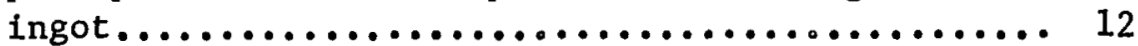

7. Initial alpha spectrum from furnace shell residue... 14

8. Delayed alpha spectrum from furnace shell residue... 14

9. Initial alpha spectrum from crucible residue....... 16

10. Delayed alpha spectrum from crucible residue....... 16

11. Ingot knockout procedure................... 19

\section{TABLES}

1. Breathing zone air sample concentrations.......... 8

2. Relative isotope activity ratios as taken from figures 4,5 , and $6 \ldots \ldots \ldots \ldots \ldots \ldots \ldots \ldots \ldots \ldots \ldots$

3. Relative isotope activity ratios as taken from

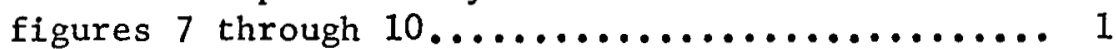




\section{RADIATION HAZARDS ENCOUNTERED IN ARC MELTING THORIUM'}

by

R. R. Lowery ${ }^{2}$

\section{SUMMARY}

This project was proposed to provide information on the hazards associated with arc melting of thorium. A general air-sampling analysis was made to determine the separation, concentration, and distribution of thorium daughter (decay) products throughout arc melting, machining, and forging processes of a thorium handling facility. The value of well coordinated health physics program is stressed in connection with potential health hazards and personnel protection. Building, equipment, and exhaust ventilation requirements for such a facility are discussed. Special handling methods are described for thorium.

\section{INTRODUCTION}

The Bureau of Mines at the Albany Metallurgy Research Center has been involved in handling the naturally radioactive metals, uranium and thorium, for several years. Cooperative work for the Atomic Energy Commission has been carried out with thorium metal, and as a result the concerned laboratories of the Center have accumulated experience on the hazards associated with this metal. This report details the radioactive hazards arising from the arc melting, machining, and forging of thorium.

It has been previously reported that when thorium metal is vacuum-cast, a separation occurs between the parent thorium $\left(\mathrm{Th}^{232}\right)$ and some of its more volatile radioactive daughter products (12)..$^{3}$ Since these isotopes are radioactive, a definite health hazard is presented to the personnel working in thorium processing areas. The extent of the hazard is dependent upon the isotopes present during various processes and their individual and combined concentrations. Therefore, the objective of this project becomes one of determining the presence and relative concentrations of isotopes in the working environment of given processes.

\footnotetext{
${ }^{1}$ Work on manuscript completed November 1960.

${ }^{2}$ Physicist, Albany Metallurgy Research Center, Bureau of Mines, Albany, Oreg. ${ }^{3}$ Underlined numbers in parentheses refer to items in the bibliography at the end of this report.
} 


\begin{tabular}{|c|c|c|c|c|c|}
\hline $\begin{array}{l}\text { Th } \\
90\end{array}$ & $\begin{array}{l}\mathrm{Th}^{232}, \mathrm{Th} \\
\text { (thorium) } \\
1.39 \times 10^{10} \\
\text { years }\end{array}$ & & $\begin{array}{l}\mathrm{Th} \mathrm{h}^{228}, \mathrm{RdTh} \\
\text { (radiothorium) } \\
1.90 \text { years }\end{array}$ & & \\
\hline $\begin{array}{l}A C \\
89\end{array}$ & $a$ & $\begin{array}{l}\mathrm{Ac}^{228}, \mathrm{MsTh}_{2} \\
\text { (meso- } \\
\text { thorium2) } \\
6.13 \text { hours } \\
\end{array}$ & $\beta$ & & \\
\hline $\begin{array}{l}\text { Ro } \\
88\end{array}$ & \begin{tabular}{|c}
$\mathrm{Ra}^{228}, \mathrm{MsTh}_{1}{ }^{\prime}$ \\
$($ meso- \\
thorium I) \\
6.7 years
\end{tabular} & $\beta$ & $\begin{array}{r}\mathrm{Ra}^{224}, \mathrm{ThX} \\
\text { (thorium } \mathrm{X} \text { ) } \\
3.64 \text { days }\end{array}$ & & \\
\hline $\begin{array}{l}F r \\
87\end{array}$ & & & $a$ & & \\
\hline $\begin{array}{c}\mathrm{Rn} \\
86\end{array}$ & & & $\begin{array}{c}\mathrm{Rn}^{220}, \mathrm{Tn} \\
\text { (thoron) } \\
54.5 \text { seconds } \\
\end{array}$ & & \\
\hline $\begin{array}{l}A t \\
85\end{array}$ & & & $a$ & $\begin{array}{c}A t^{216} \\
3 \times 10^{-4} \text { seconds }\end{array}$ & \\
\hline $\begin{array}{l}\text { Po } \\
84\end{array}$ & & & $\begin{array}{c}\text { Po }{ }^{216}, \text { ThA } \\
\text { (thorium A) } \\
0.158 \text { second }\end{array}$ & $\beta(0.013 \%)$ & \begin{tabular}{|}
$\mathrm{Po}^{212}, \mathrm{ThC}^{\prime}$ \\
(thorium $\mathrm{C}^{\prime}$ ) \\
$3 \times 10^{-7}$ second
\end{tabular} \\
\hline $\begin{array}{r}\mathrm{Bi} \\
83\end{array}$ & & & $\mid \begin{array}{l}\alpha \\
(-100 \%)\end{array}$ & $\begin{array}{c}\mathrm{Bi}^{2 ! 2}, \mathrm{ThC} \\
\text { (thorium } \mathrm{C}) \\
60.5 \text { minutes } \\
\end{array}$ & $\beta(66.3 \%)$ \\
\hline $\begin{array}{l}\mathrm{Pb} \\
82\end{array}$ & & & $\begin{array}{l}\mathrm{Pb}^{212}, \mathrm{ThB} \\
\text { (thorium } \mathrm{B}) \\
10.6 \text { hours }\end{array}$ & \begin{tabular}{|l|l|}
$\beta$ & $\alpha$ \\
& $(33.7 \%)$ \\
\end{tabular} & $\begin{array}{c}\mathrm{Pb}^{208}, \mathrm{ThD} \\
\text { (stable } \\
\text { lead isotope) }\end{array}$ \\
\hline 81 & & & & $\begin{array}{l}T^{200} ; T h C^{\prime \prime} \\
\left.\text { (thorium } C^{\prime \prime}\right) \\
3.1 \text { minutes }\end{array}$ & $\beta$ \\
\hline
\end{tabular}

FIGURE 1.- The Thorium Decay Series.

\section{Thorium Decay Series}

The radiotoxicity of thorium itself is not so great as that of the members of its decay chain. This is because the daughters deliver more energy by decay during the concerned periods (human lifetimes) than the thorium 232 parent. Consequently, an understanding of the chain and its contributions to the total radioactivity of thorium is essential in order to appreciate the health hazards that can develop in thorium metallurgy. The decay products of thorium have half lives that cause complicated patterns of growth and decay, especially after a separation of certain isotopes. Natural thorium usually contains two thorium isotopes, thorium 232 and thorium 228 , the second being present to a minute fraction of the first. The immediate descendants of thorium 232 and thorium 228 are (fig. 1) radium 228 and radium 224, respectively, formed by alpha decay. These decay in two different ways. Radium 228 is a beta emitter with a half life of 6.7 years, giving actinium 228 (mesothorium 2), which is the immediate parent of thorium 228 by a second beta decay. Radium 224 is an alpha emitter with a half life of 3.64 days, giving an inert gas isotope radon 220 that decays by alpha emission with a half life of about one minute and is followed by polonium, lead, bismuth, and thallium isotopes with relatively short half lives. The equilibrium between isotopes is another factor that must be considered when analyzing thorium daughters as potential hazards. This state of equilibrium is especially. important when chain-breaking separations are known to occur during the concerned processing.

In considering equilibrium of radioactive pairs (parent and daughter), one can distinguish general cases, depending upon which of the two substances has the longer half life. 
If the parent is longer lived than the daughter, a state of so-called radioactive equilibrium is reached; that is, after a certain time the ratio of the numbers of atoms and consequently the ratio of the decay rates of parent and daughter become constant. There are two types of radioactive equilibriums usually discussed, secular and transient equilibrium.

1. Secular equilibrium occurs when the parent activity does not measurably decrease during many daughter half lives. After a few half-lives the daughter substance will reach its equilibrium value, at which time its rate of decay equals its rate of production. Applying secular equilibrium ideas to natural (thorium minerals) or very old thorium gives an example. Referring to thorium 232, radium 228, actinum 228, and so on as $1,2,3$, and so on, in their genetic sequence, we see that $\mathrm{N}_{2}$, the number of radium 228 atoms, must be constant. Because $\mathrm{N}_{2}$ is fixed, the decay rate of 2 must be constant also; hence, 3 is in secular equilibrium too; so is every other radioactive member of the series. Thus $N_{1} \lambda_{1}=N_{2} \lambda_{2}=N_{3} \lambda_{3}=N_{n} \lambda_{n}$, where the $N^{\prime}$ 's and $\lambda^{\prime}$ 's are the numbers of atoms and the decay constants of the respective isotopes; the subscript indicates the member of the series. In such a sequence, (1) every member is present in constant but different amounts, (2) the number of atoms of the various members present are proportional to their half lives, and (3) every radioactive member is decaying and (with the exception of the first) being produced at the same rate; $\mathrm{N}_{1} \lambda_{1}$. A restriction on the stated equation is that no chemical or physical separations have been made on the sample for a period that is long compared to the second longest half life in the sequence.

2. If the half life of the parent is sufficiently short, so that the quantity present decreases appreciably during the period under consideration, but is still longer than that of the successive members of the series, a state of equilibrium will be reached after which all members of the series decrease in amount exponentially with the half life of the parent. This condition is known as transient equilibrium, and an example is the decay of 3.64-day radium 224 to form the 54.5-sec. radon 220. Starting with a pure radium 224 sample the activity due to radon 220 would increase for several minutes and then would decrease steadily with a 3.64-day half life.

If the parent is shorter lived than the daughter, it is evident that no equilibrium is attained. If the parent is initially free of the daughter then as the parent decays, the amount of the daughter will rise, pass through a maximum, and eventually decay with the characteristic half life of the daughter.

\section{Radiotoxicity of Thorium}

In general, the radiotoxicity of any radioactive material is described in terms of external and internal radiation. The principal hazard from thorium or thorium wastes as an external source of radiation is derived from the high (2.62 million electron volts) gamma radiation of the thallium 208 isotope of the thorium decay series. On the other hand, the internal hazard includes alpha and beta emissions as well as many other complicated factors. Determinants such as the site of deposition within the body (cuts, lungs, digestive tract, and so forth), the fraction of the administered dose (inhalation,

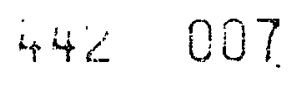


ingestion, and so forth) that. reaches location, and rate of elimination of the material after it is fixed are important in determining the internal radiotoxicity of radioactive materials. In addition to the mentioned damage determinants, a term of primary importance for the study of biological damage is linear energy transfer (LET). That is, the energy locally absorbed per centimeter of particle path. The rate of this energy absorption is of course dependent upon the type of tissue through which the particle passes and, of greater importance, the mass of the emitted particle. For example, the beta particle, because of its small mass, can travel considerable distance in tissue before exhausting its energy and therefore cause a low density of tissue damage (ionized, disrupted, and excited tissue molecules). The alpha particle with its greater mass loses its energy in a much shorter distance and causes a localized area of tissue damage. Due to this localized disturbance, alpha emission produces more severe internal damage than an equivalent energy of beta emission. It should be noted with respect to the above comparison that the thorium series decays primarily by alpha emission and thus is most hazardous as an internal radiation source.

Extensive work at the University of Utah on dogs has provided some information on the biological behavior of the thorium chain members (17, 18).

\section{Thorium Metallurgical Processes}

Three major thorium metal handling processes are being studied by the Bureau of Mines at the Albany Metallurgy Research Center: (1) Arc melting thorium ingots, (2) machining these ingots to forging stock, and (3) forging the ingots. All work on thorium with which this paper is concerned began with thorium in a metallic form, usually previously melted ingots, provided by the Atomic Energy Commission from thorium unused by the Savannah River Breeder Experiment.

\section{Arc Melting}

The production of ingots by consumable-electrode arc melting in vacuum or inert atmospheres has been successfully applied to the processing of many reactive metals including thorium. The melting process begins with the formation of an electrode. In the case of thorium this electrode can consist of sawed bomb regulus bars butt-welded together or a previously induction-melted or. arc-melted ingot. The electrode is mounted vertically in an appropriate furnace such as shown in figure 2 and is consumed by heat from a high-current electric arc that burns at the lower end of the electrode. The metal consumed by the arc drops into a water-cooled copper crucible where an ingot is formed by solidification. When the ingot is completely cool, the furnace is opened, and the ingot is removed from the crucible for machining. Sometimes it is necessary to remelt or "double-melt" to obtain homogeneity. A complete description of the consumable-electrode arc-melting procedure for thorium was given by Roberson and Beall (14). 


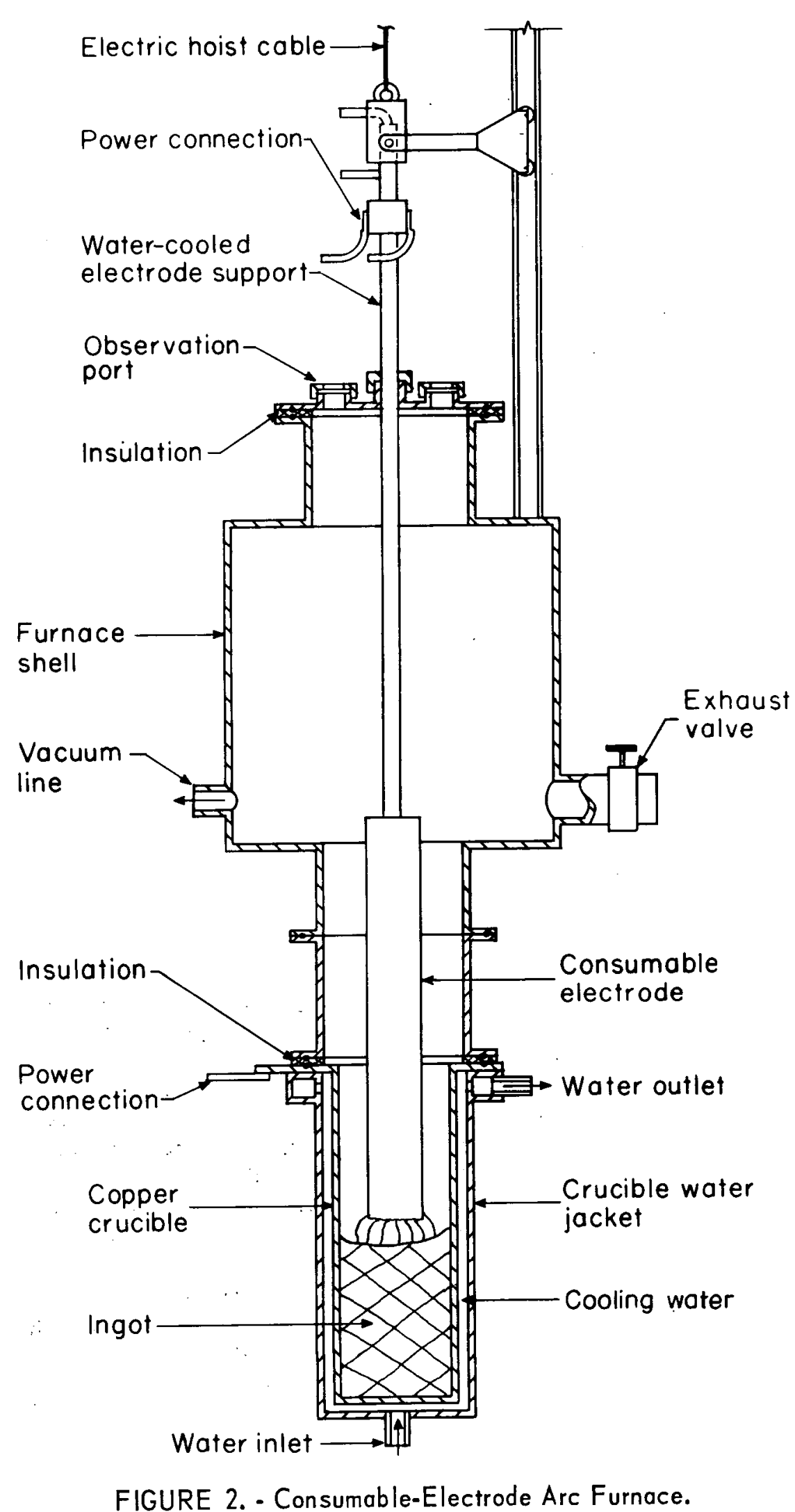

\section{Machining}

A characteristic of an arc-melted ingot is the presence of a shrink hole, or an area of porosity, at or near the top of the ingot. This results from the rapid cooling of the molten pool after extinguishing the arc. This hole or porosity must be removed before the ingot can be forged; this is usually done by sawing or machining off the end of the ingot. In addition to the removal of the shrink hole, the sidewall and bottom of the ingot are sometimes rough or porous and need machining.

\section{Forging}

The machinefinished ingot goes through normal handling procedure in the forging area. The ingot, heated in an electrically heated muffle furnace to the proper degree for forging, is formed into a billet in a forging press. The resulting billet is then reheated and sent through a rolling mill in successive passes until the appropriate thickness is reached.

\section{ACKNOWLEDGMENTS}

The author gratefully acknowledges the cooperation of Seymour 
Block and Jack L. Brown of Lawrence Radiation Laboratory, University of California, who provided the alpha and gamma energy spectrums for the various samples. The research was supported by a cooperative agreement with the Atomic Energy Commission.

\section{EXPER IMENTAL PROCEDURE AND RESULTS}

Two general methods were adopted for obtaining analysis samples from the operating areas. A majority of the collected samples were of the breathing zone type; that is, high-volume air samples taken as near as possible to the breathing zones of operating personnel. These samples were considered representative of the airborne materials that could be inhaled if no mask or respirator protection were used. In addition to the air samples, several residue samples were collected from the interior of an arc furnace immediately after a thorium melt.

\section{Breathing Zone Air Sampling}

Air samples were taken with a high-volume sampler mounted on an adjustable stand, which permitted samples to be collected from the breathing zone of the operating personnel. This particular air sampler utilized a 4-inchdiameter collection filter paper, and for this work T. F. A. 非 41 type paper was used. The air volume sampled for most collections averaged about 300 cubic feet and was collected at a rate of 20 to 22 cubic feet per minute. This volume was considered adequate for all operations. These collected samples were analyzed in two different ways. All samples were counted for alpha and beta emissions at the Albany Metallurgy Research Center. Some selected samples were sent to the University of California Lawrence Radiation Laboratory where they were counted by pulse-height analysis techniques.

Analysis by Absorption and Decay

The counting equipment available for this analysis was quite simple, and, as a result, the data obtained have limitations. The equipment consisted of an end-window mica counter tube enclosed in a manual sample changer protected by 2 inches of lead covered with aluminum. The sample-changer slide was machined to take 1-inch-diameter disks of sample paper that were randomly punched from the 4-inch filter papers used for collection. The counter tube assembly was connected to a decade scaler that reoorded total counts. Counting time was set by a timer and measured to tenths of a second by a small precision clock. At each decay time, all samples were counted once for total alpha and beta radiation and a second time for beta radiation by introducing an aluminum absorber between the counter tube and the sample. Thus, by subtracting the beta count from the total count, the approximate alpha count could be found. Since it was impossible to discriminate between the emitting isotopes by use of this relatively rudimentary counting equipment, samples were counted several times over a period of two weeks to produce decay curves. It was hoped that some half-life determinations from these decay curves would help to provide isotope identification.

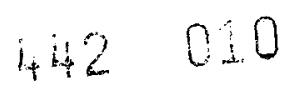


Table 1 contains a summary of the breathing zone air samples taken, the operations covered by sampling, and the short-lived and long-lived total activities, converted from disintegrations per minute to microcuries per milliliter (d.p.m。to $\mu \mathrm{c} . / \mathrm{ml}$ ) of samples as found by the aforementioned counting techniques. The listed activities give an order of magnitude of the concentrations during various operations.

Some uncertainty exists in the maximum permissible concentration (M.P.C.) of thorium 232 recommended by the National Committee on Radiation Protection. Several authorities recommend that the value be set much lower than $3 \times 10^{-1 i}$ $\mu \mathrm{c} / \mathrm{ml}(10)$. These recommended M.P.C. values are as low as $1 / 50$ of the $3 \times 10^{-11} \mu \mathrm{c} / \mathrm{ml}$ value. $(\underline{8}, \underline{15})$

A closer look at table 1 shows that there were three operations that did not decay to the $3 \times 10^{-11} \mu \mathrm{c} / \mathrm{ml}$ value in the long decay period. These operations were: Arc furnace unloading, ingot knockout, and ingot machining. Since these operations produced the highest airborne contamination, the greatest effort was devoted to analyzing them. Activity decay curves were plotted for samples taken during these operations. The decay curves were analyzed graphically for evident half lives. In the analyses of the decay curves, it was only possible to determine the approximate short-lived component half lives by graphical methods. The longer lived components must be analyzed in some other manner. Determination of the short-lived components of the samples representing unloading of arc furnaces showed that the half lives approached the 10.6-hour period of lead 212. This would be expected if radon ( $\mathrm{Rn}^{220}$ ) were the major air contaminant. This was probably the case during opening and unloading of furnaces since little or no mechanical jarring occurred to stir up residues from the furnace and crucible. The gaseous isotope radon 220 present could have escaped from the rough residue wall of the unmachined thorium ingot, or it could have been present in the room atmosphere. On the other hand, the residues of the crucible were liable to become airborne when the ingot was knocked out. Samples taken during this knockout operation had short-lived components that decayed with approximately 3.64-day half lives. This is the decay period of radium 224, the immediate daughter of thorium 228 and the partner isotope of radium 228. This radium 224 could have decayed from a quantity built up by separation and concentration effects of the arc melting; or it could have been the result of the decay of radium 228 (also perhaps concentrated by the arc-melting process) through actinium 228 and thorium 228. Samples taken near a lathe during machining of rough arc-melted ingots also had short-lived components of 3.64-day half lives. This was probably a carryover of the same material stirred up during ingot knockout. That is, the residues along the exterior of the ingot were stirred up by the first few scalping cuts of the lathe just as they were by the ingot knockout operation. The lathe was equipped with only local exhaust hose ventilation in this case. After the lathe was completely enclosed in a ventilated hood, the short-lived component of the samples dropped in half life to the 10.6-hour period of lead 212. This indicated that the material that contributed the radium 224 was being contained and removed by the hood. Again, the lead 212 (the controlling isotope of decay of radon 220) probably arose from the radon 220 collected from the room atmosphere.

$$
442 \quad 011
$$


TABLE 1. - Breathing zone air sample concentrations

\begin{tabular}{|c|c|c|c|c|c|}
\hline \multirow[b]{3}{*}{ Operation sampled } & \multirow{3}{*}{$\begin{array}{l}\text { Number of } \\
\text { samples } \\
\text { collected }\end{array}$} & \multicolumn{4}{|c|}{ Average concentration $(\mathrm{uc} / \mathrm{ml})$} \\
\hline & & \multicolumn{2}{|c|}{ Alpha } & \multicolumn{2}{|c|}{ Beta } \\
\hline & & $\begin{array}{l}\text { Short decay } \\
(24 \text { hours })\end{array}$ & $\begin{array}{l}\text { Long decay } \\
(2 \text { weeks) }\end{array}$ & $\begin{array}{l}\text { Short decay } \\
(24 \text { hours })\end{array}$ & $\begin{array}{l}\text { Long decay } \\
\text { (2 weeks }\end{array}$ \\
\hline \multicolumn{6}{|c|}{ MELT ING } \\
\hline 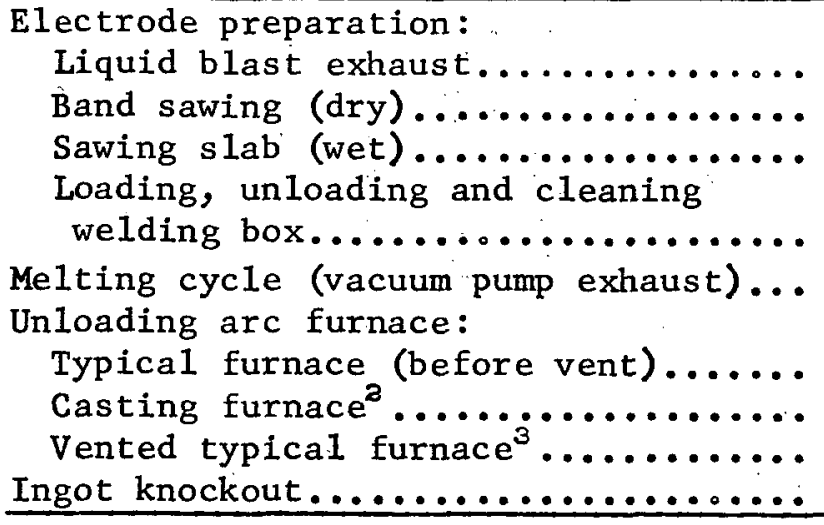 & $\begin{array}{l}1 \\
2 \\
1 \\
4 \\
2 \\
7 \\
1 \\
1 \\
6\end{array}$ & $\begin{array}{l}1.05 \times 10^{-11} \\
2.15 \times 10^{-10} \\
3.70 \times 10^{-11} \\
2.46 \times 10^{-10} \\
(1) \\
4.68 \times 10^{-9} \\
1.88 \times 10^{-8} \\
1.04 \times 10^{-9} \\
5.83 \times 10^{-9}\end{array}$ & $\begin{array}{l}\left(^{1}\right) \\
1.45 \times 10^{-11} \\
3.64 \times 10^{-12} \\
3.56 \times 10^{-11} \\
- \\
6.99 \times 10^{-10} \\
1.94 \times 10^{-9} \\
1.32 \times 10^{-10} \\
9.02 \times 10^{-10} \\
\end{array}$ & $\begin{array}{c}8.42 \times 10^{-12} \\
4.44 \times 10^{-10} \\
7.03 \times 10^{-11} \\
4.16 \times 10^{-10} \\
- \\
4.61 \times 10^{-9} \\
1.10 \times 10^{-8} \\
1.50 \times 10^{-9} \\
6.04 \times 10^{-9} \\
\end{array}$ & $\begin{array}{c}\left({ }^{1}\right) \\
3.52 \times 10^{-11} \\
3.64 \times 10^{-12} \\
9.93 \times 10^{-11} \\
- \\
1.53 \times 10^{-9} \\
2.44 \times 10^{-9} \\
5.71 \times 10^{-10} \\
1.95 \times 10^{-9} \\
\end{array}$ \\
\hline \multicolumn{6}{|c|}{ MACHINING } \\
\hline 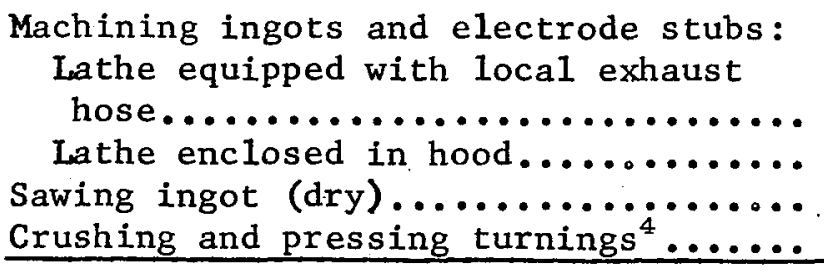 & $\begin{array}{l}6 \\
5 \\
1 \\
2 \\
\end{array}$ & $\begin{array}{l}2.49 \times 10^{-9} \\
3.9 \times 10^{-10} \\
3.5 \times 10^{-11} \\
9.59 \times 10^{-10} \\
\end{array}$ & $\begin{array}{c}3.12 \times 10^{-10} \\
1.70 \times 10^{-11} \\
\left({ }^{1}\right) \\
2.72 \times 10^{-10}\end{array}$ & $\begin{array}{l}1.97 \times 10^{-9} \\
5.18 \times 10^{-10} \\
1.08 \times 10^{-10} \\
1.54 \times 10^{-9} \\
\end{array}$ & $\begin{array}{l}4.59 \times 10^{-10} \\
3.1 \times 10^{-11} \\
\left({ }^{1}\right) \\
9.67 \times 10^{-10} \\
\end{array}$ \\
\hline \multicolumn{6}{|c|}{ FORGING } \\
\hline $\begin{array}{l}\text { Removing ingot from heating furr } \\
\text { Forging ingot to billet....... } \\
\text { Rolling billet to slab....... }\end{array}$ & $\begin{array}{l}2 \\
4 \\
3 \\
\end{array}$ & $\begin{array}{l}1.65 \times 10^{-11} \\
3.90 \times 10^{-11} \\
9.5 \times 10^{-11} \\
\end{array}$ & $\begin{array}{l}\left({ }^{1}\right) \\
1.94 \times 10^{-11} \\
7.14 \times 10^{-11}\end{array}$ & $\begin{array}{l}1.66 \times 10^{-11} \\
5.17 \times 10^{-11} \\
1.07 \times 10^{-10}\end{array}$ & $\begin{array}{l}\left({ }^{1}\right) \\
1.29 \times 10^{-11} \\
6.57 \times 10^{-11}\end{array}$ \\
\hline
\end{tabular}

${ }^{1}$ No detectable count.

${ }^{2}$ Molten metal was poured over the lip of a ladle into a mold in this type of furnace.

${ }^{3}$ This single sample may not be representative of vented furnace operation since time did not permit more samples to be taken.

${ }^{4}$ This was not a normal operation but a specialized case of material recovery. If this type of operation were to be done regularly, it would have to be carried out in a room with a very high ventilation rate. 
These results indicate that there was a separation and concentration of radium by the arc-melting process. The separation may be radium 228 or both radium 228 and radium 224 . In either case the separation was undoubtedly reached by volatilization of the radium from the thorium during melting and condensation of the radium when it reached the cool surfaces of the furnace.

A comparison of the vapor pressure relationships of thorium, actinium, and radium makes it simple to justify the volatilization of radium during an arc melt. The relative boiling temperatures (where the metal vapor pressure equals the atmospheric pressure) are most readily found and visualized. Thorium boils at about $4,000^{\circ} \mathrm{C}$, and actinium boils at approximately $3,300^{\circ} \mathrm{C}$, whereas radium boils or volatilizes at a much lower temperature of about $1,135^{\circ} \mathrm{C}$.

\section{Pulse-Height Analysis}

The counting technique used in the melting laboratory of the Albany Meta1lurgy Research Center was not designed to. discriminate between different alphaemitting isotopes. Therefore, the University of California Lawrence Radiation Laboratory was requested to analyze, some air samples for this project, with hopes of discriminating between the different alpha-emitting isotopes of the thorium decay chain. The more elaborate pulse-height analysis equipment of the Lawrence Radiation Laboratory, combined with their greater experience with this type of analysis, yielded more useful data than could be obtained from the counting equipment available locally.

Isotopes that decay by alpha emission give off alpha particles of discrete energies, and these energies may be used to identify the emitting isotopes. This energy distribution of alpha activities is determined by counting the samples in a Frisch grid ionization chamber, which produces electrical pulses proportional in voltage to the energy of the alpha particle causing the ionization. Pulse-height analysis equipment takes advantage of this discrete energy characteristic of alpha particles to use the preceding method of counting for producing alpha energy spectrums.

Samples from the three most hazardous operations were sent to the Lawrence Radiation Laboratory for processing by pulse-height analysis :
(1)
Unloading arc furnaces,
(2) ingot knockout, and
(3) machining ingots.

First, the samples were analyzed for alpha radiations by mechanically removing a part of the collection paper for counting. Figure 3 shows the typical result of these analyses. : The energy calibration curve was obtained by using alpha-emitting standards of known energies. The energies of the curve peaks were then found by projecting to the calibration curve and energy scale as illustrated by the dotted line drawn from the polonium 216 peak. As can be seen by the pulse curve labeling, all the alpha-emitting short-lived daughters of the thorium chain are present on the figure. The relative peak heights of the pulses could be used as an approximate ratio of the concentrations of the daughters with respect to each other, but there was no way of determining the exact concentrations during the operation sampled because of sample decay problems and the fact that the original proportions of isotopes

$$
442013
$$




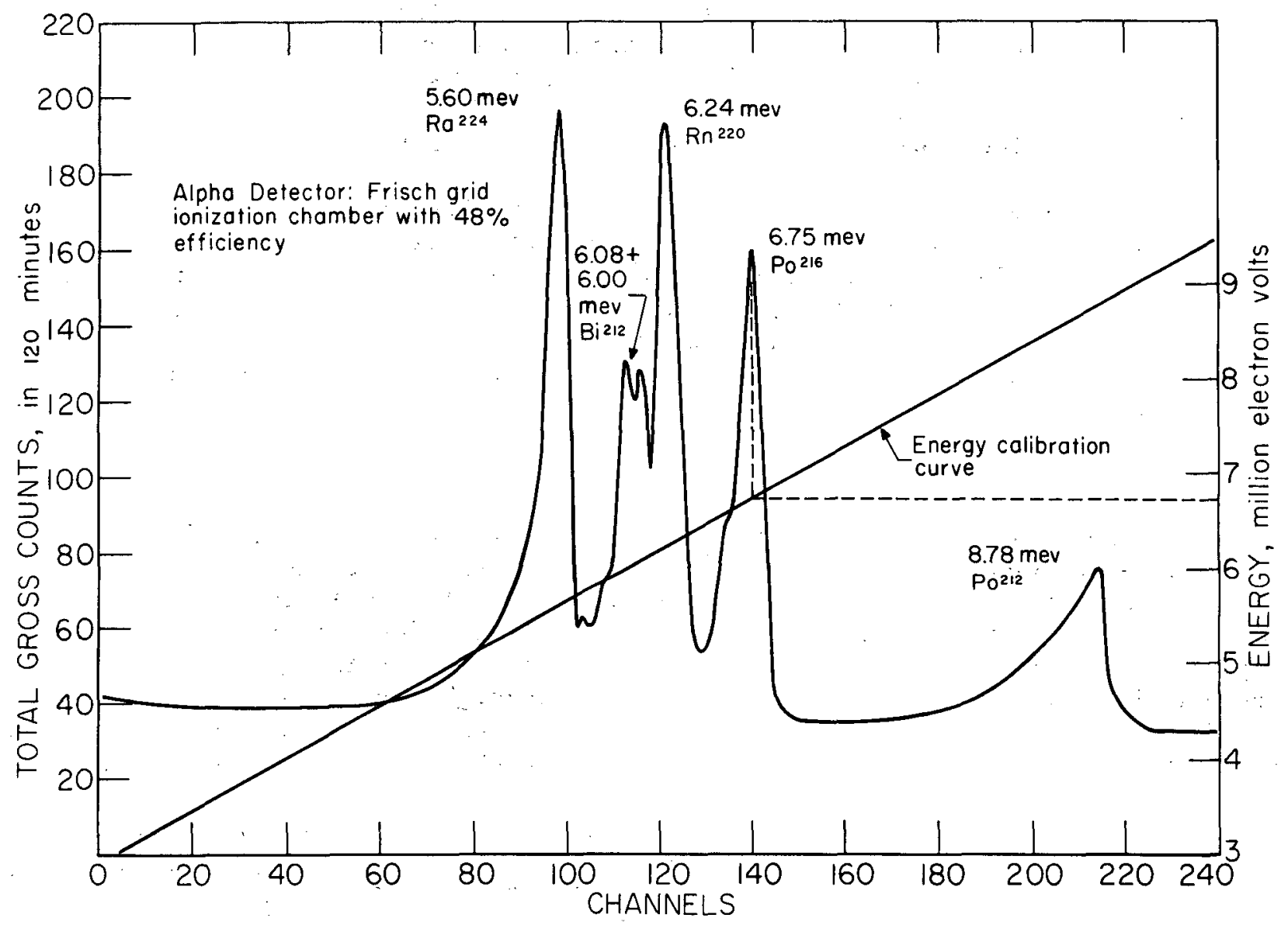

FIGURE 3. - Typical Alpha Spectrum of Shorf Lived Thorium Chain Isotopes.

present on the samples may not be retained during mechanical transfer of that section of collection paper. As can be seen in figure 3, there were no longer lived isotope pulses shown. In order to make them evident, the samples were chemically processed to concentrate the longer lived isotopes. To obtain this concentration of isotopes, the samples were dissolved and run through a separation by ion exchange resin columns, which was designed to concentrate the longer lived isotopes of thorium, radium, and actinium but not the lead. Once the separation was complete, the samples were again analyzed for alpha radiations. Figures 4, 5, and 6 show the results for the three operations. The pulse heights are labeled in million electron volts corresponding to the energy represented by the peaks. The isotope that can be identified by that specific energy is listed next to its respective peak. An order of magnitude of the relative concentration between various operations can be approximated by reading counts on the ordinates of the respective pulse-height curves. The relatively high concentration shown in figure 5 may be attributed directly to the mechanical handling involved in the operation. The unloading of furnaces and machining of ingots were relatively unagitated mechanical operations, but the ingot knockout (fig. 5) was just the opposite. In this operation, the copper crucible was turned upside down and jarred until the ingot dropped. The dropping of the ingot stirred up the available residues along the walls

$$
442 \cdots 014
$$




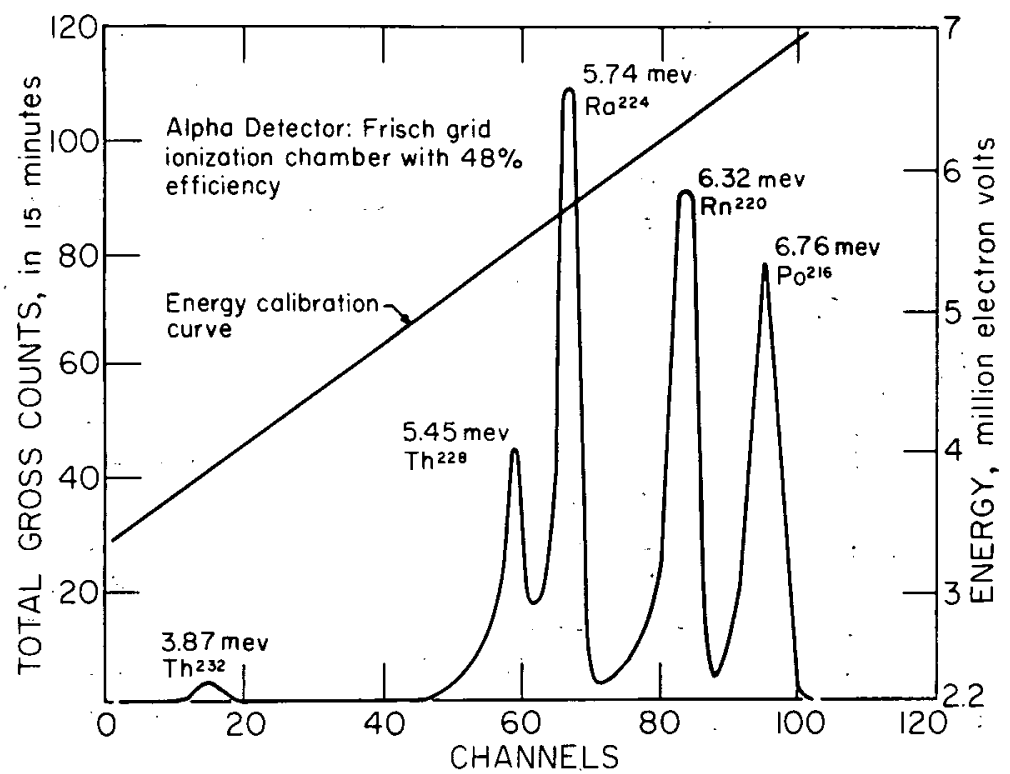

FIGURE 4. - Alpha Spectrum of Air Sample From Unloading of Furnace.

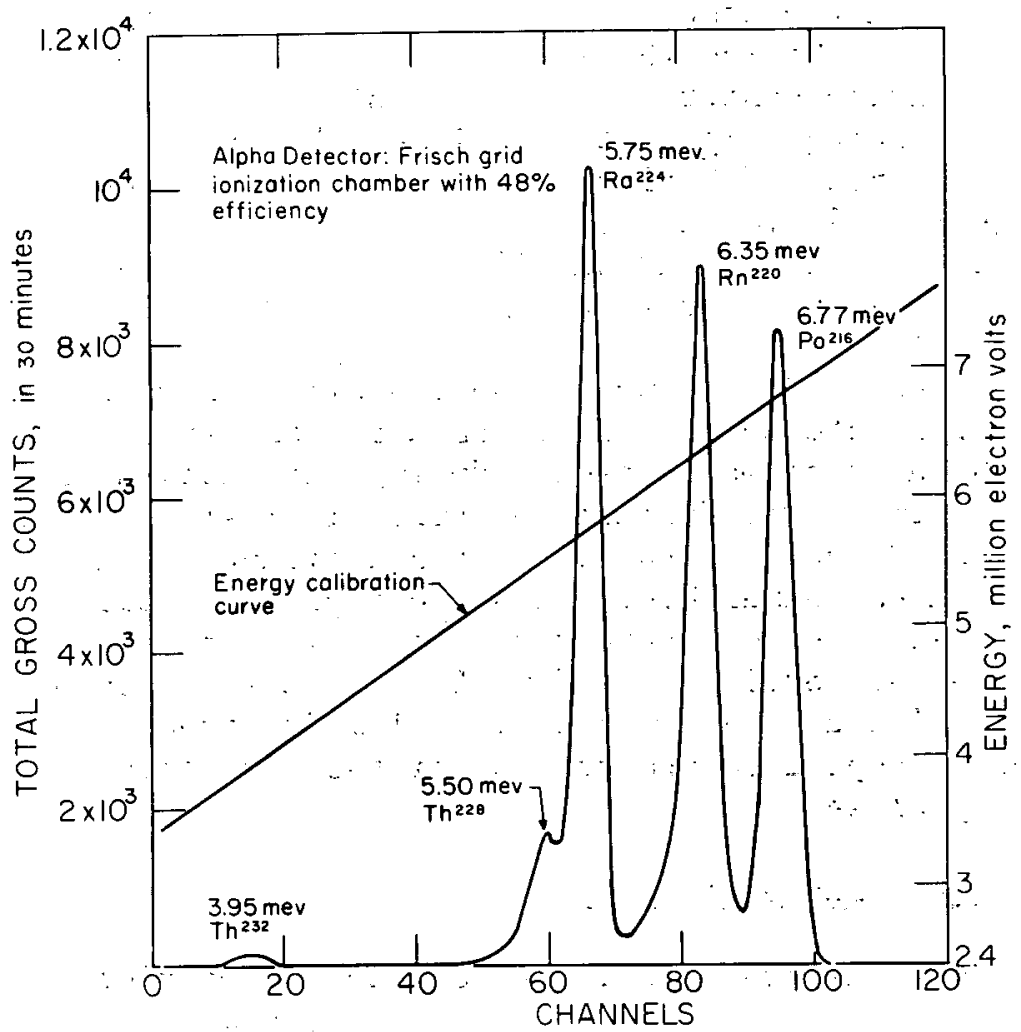

FIGURE 5. - Alpha Spectrum of Air Sample From Ingot Knockout. of the crucible, and they in turn became airborne, accounting for the high activity.

Natural or normal thorium usually contains only a minute percentage of the thorium 228 isotope. Examination of figures 4,5 , and 6 shows that there was an excess of thorium 228 present. This confirms that radium 228, and its daughter thorium 228, were separated by the high temperature reached during the melting cycle.

A comparison of figures 4, 5, and 6 from the standpoint of relative activities of the measured isotopes is interesting. In order to obtain exact proportions of the isotopes, it would be necessary to compare the individual alpha peak areas, but for this comparison the relative heights of the peaks are a sufficient measure of the relative activities. For each figure the relative activities of the individual isotopes are quoted as ratios based upon the thorium 232 height as unity. That is, for each figure the ratio values are worked out on the basis of the thorium 232 height being unity for that figure. So, in figure 4 the ratio of thorium 232 to thorium 228 ratio is 1 to 10.4 , or the value of thorium 228 is 10.4 . Ratios between parent and daughter isotopes are given as interisotope ratios. Table 2 gives these ratios 


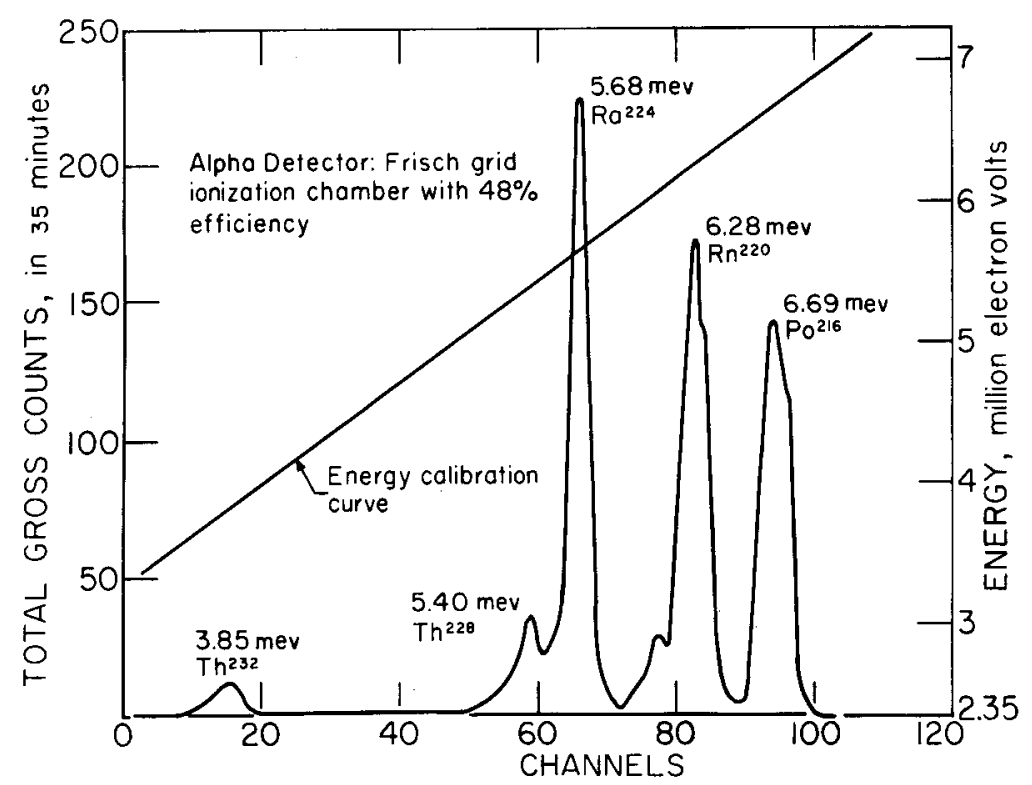

FIGURE 6. - Alpha Spectrum of Air Sample From Machining of Ingot. of the respective isotopes as taken from the three figures.

An examination of table 2 shows that there was a gross difference between the proportions of thorium 228 present in the three samples. This difference may be explainable from the view of the material content of the respective air samples. The unloading and knockout samples (figs. 4 and 5) contained the same proportion of thorium 228. This was probably because furnace and crucible residues (containing radium 228 from which thorium 228 grows) contributed the major amount

of air contaminant in both cases. On the other hand, the machining step differed from the other two in that more thorium 232 may have become airborne as a result of the lathe cutting operation penetrating deeper into the pure thorium metal. Therefore, in the machining sample, the ratio of thorium 228 to thorium 232 was less because of the higher thorium 232 content of the sample. The interisotope ratios agree quite well for the three samples except in the case of those ratios between thorium 228 and radium 224. In that case there was a greater proportion of radium 224 present in the knockout and machining samples than in the unloading sample. This variance can be explained by a comparison of the handling procedures. If radium was boiled off during melting of thorium and condensed on the interior of the furnace and crucible walls, it would have become airborne much more readily during the knockout and machining steps than during unloading. The furnace and crucible residues were relatively undisturbed during unloading, and probably a small amount of the total residue became airborne. On the other hand, when the ingot knockout and machining were performed, these residues were agitated to a larger degree, accounting for the higher airborne proportion of radium 224. The interisotope ratios of table 2 also show that although the amount of radium 224 present varied for the three samples, the respective proportions of the succeeding daughters of radium 224 were very close.

\section{Furnace Residue Sampling}

Experience has shown that residues from arc furnaces used for melting thorium have very high activities. Therefore, it was decided to take actual scrapings of a furnace interior following a thorium melt for analysis. Samples were taken from two areas inside the arc furnace. Scrapings were first taken from the steel walls of the furnace chamber itself, and, secondly, residues were taken from the exposed vertical walls of the water-cooled copper 
melting crucible. These two sets of samples were sent to the Lawrence Radiation Laboratory for alpha pulse-height analysis. Two types of pulse-height analyses were furnished, one for alpha and an additional analysis for gamma radiation, in order to obtain information on isotopes that do not decay by alpha radiation. No precounting preparation of the scrapings was necessary for the gamma analyses. The residues were merely spread on a planchet and counted by a 3-inch scintillation head covered with sodium iodide sensing crystals. The sample preparation for alpha analyses was more complicated. Small metallic pieces were mechanically separated from the residues and dissolved in concentrated hydrochloric acid. The solution was then evaporated to dryness, formed into a ball, and volatilized onto a 1-inch planchet for alpha pulse-height counting in a Frisch grid chamber.

TABLE 2. - Relative isotope activity ratios as taken from figures 4,5 , and 6

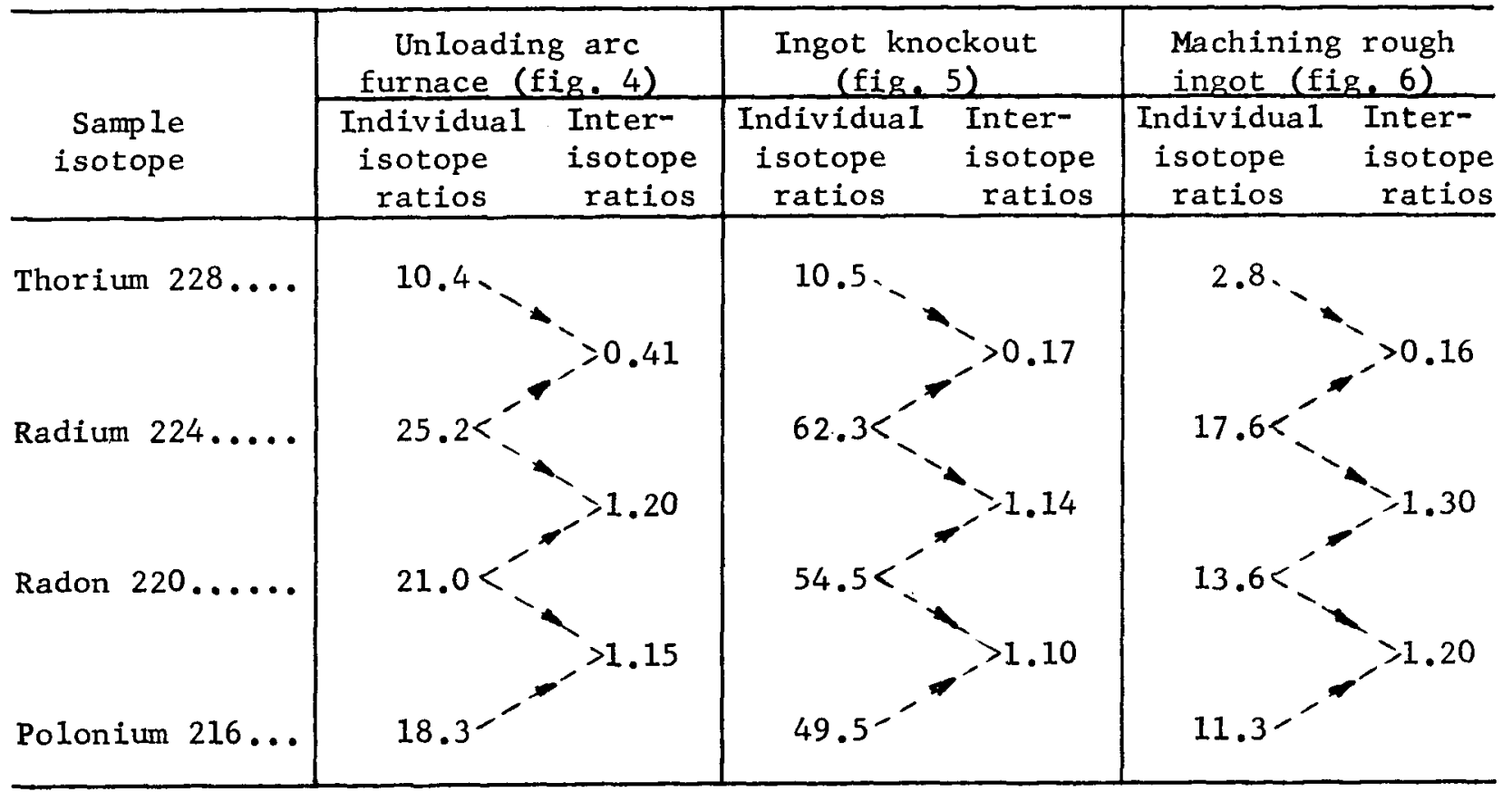

The gamma analyses for both the furnace shell and crucible wall samples showed thorium 228, lead 212, and thallium 208 to be present by the recordings of respective gamma energies of $83.5 \mathrm{Kev} ., 239 \mathrm{Kev} .$, and $582 \mathrm{Kev}$. Again, the concentrations of isotopes within the furnace areas were not readily calculable because it was not possible to relate the percentage of furnace area scraped to the respective samples.

The alpha pulse-height analyses were done twice for each sample in hopes that some idea of isotope decay or growth within the sample could be acquired. The second analysis was done approximately eight days after the first. A comparison of the two analyses exposed some interesting growths and decays that were important in estimating separations that occurred in the arc furnaces. Figures 7 and 8 represent the first and second analysis, respectively, of the

$$
4 \div 07
$$




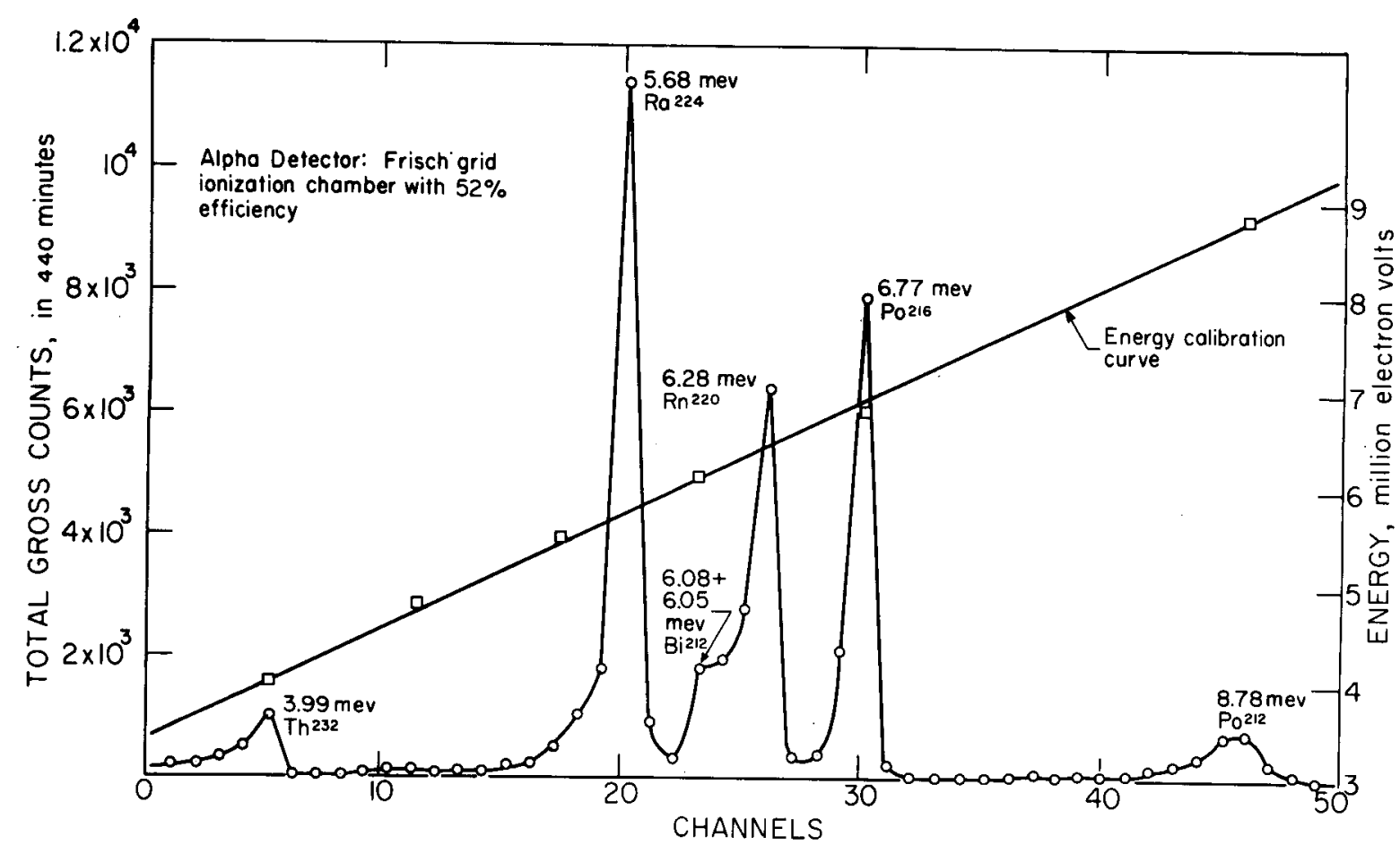

FIGURE 7. - Initial Alpha Spectrum From Furnace Shell Residue.

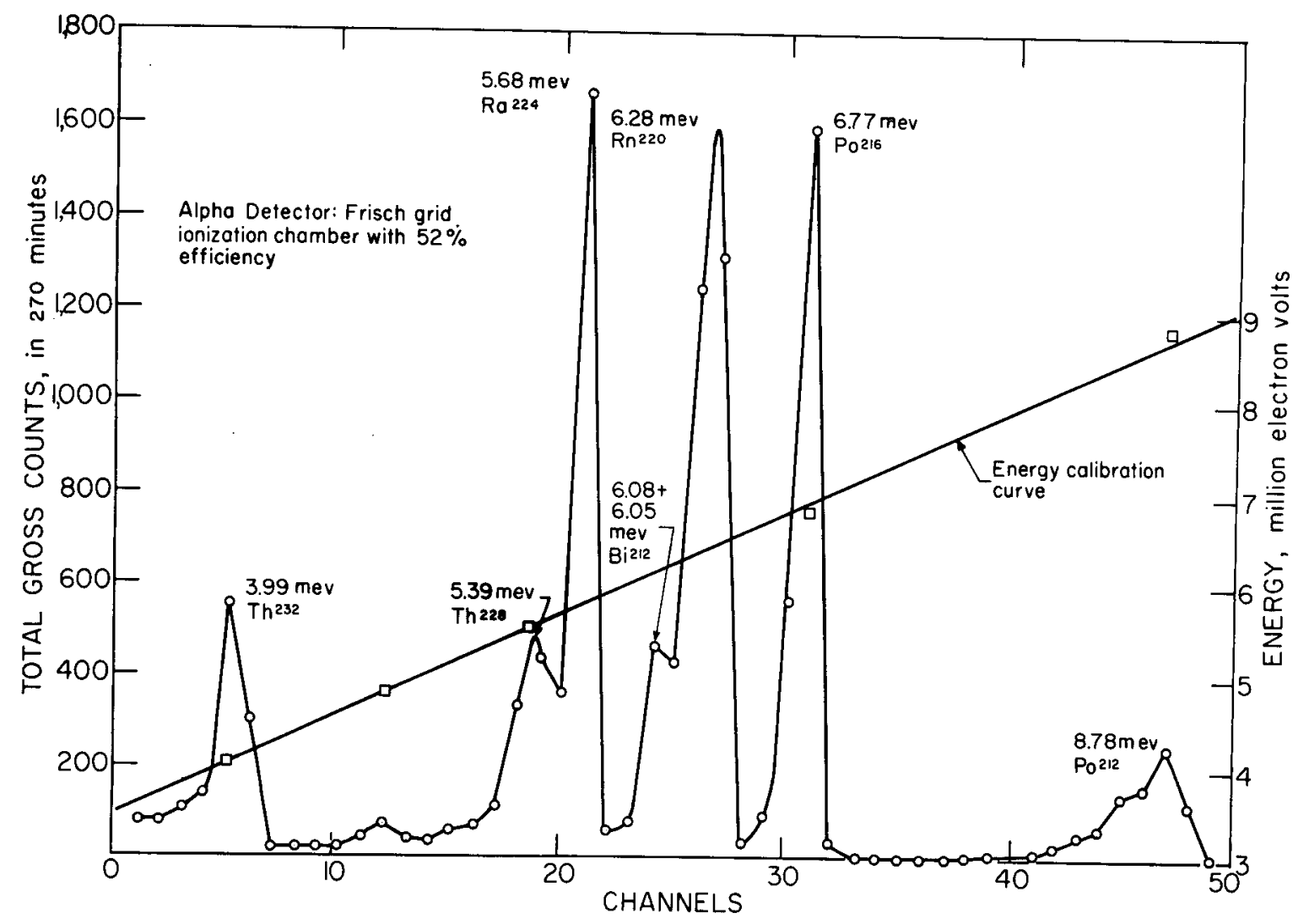

FIGURE 8. - Delayed Alpha Spectrum From Furnace Shell Residue. 
residue sample taken from the interior of the arc furnace shell walls. A close comparison of figures 7 and 8 revealed that thorium 228 was recorded in figure 8 but was not recorded in figure 7 ; which indicated that there was a growth of thorium 228 during the 8-day-delay period. This does not mean it was absent initially, because gamma pulse-height counting definitely identified the isotope. Instead, the small amount of thorium 228 was probably masked by poor counter resolution for the particular situation. The alpha analysis of the residue sample taken from the copper crucible walls is summarized in figures 9 and 10. As in figures 7 and 8, thorium 228 showed up only in the second analysis, again indicating that there was a growth of thorium 228 during the 8-day-delay period.

One way to analyze the figures 7 through 10 for isotope growth and decay is to set up a table of relative isotope activities such as table 2. This approach was followed, and table 3 lists the results. Again, the listed values are ratios of the respective isotope activities to the thorium 232 activity, which was taken as unity for each individual figure. Individual isotope ratios are shown, and the ratios between isotopes are also listed.

Examination of table 3 discloses several interesting facts. First, there was a growth of thorium 228 in both samples during the 8-day delay between alpha analyses. Second, there was a high initial concentration of radium 224 in both samples. These two occurrences can be explained by the separation of radium during arc melting. The radium isotope radium 224 was of course volatilized directly. The occurrence of a growth of thorium 228 can also be explained by the radium separation since thorium 228 is the granddaughter of the radium isotope radium 228. (This radium separation and resulting thorium 228 growth accounts for the unbalance of thorium 232 and thorium 228.)

On figures 7 and 8 it should be noted that initially (fig. 7) the radium 224 ratio was much higher than those of radon 220 and polonium 216 , which are directly below radium 224 in the decay chain. On figure 8 , after an 8-day delay, the three isotopes were relatively close to each other in concentration. This showed that there was an excess of radium 224 initially, which decayed rapidly to come into equilibrium with the radon 220 and lead 216.

An item of interest in connection with figures 7 and 9 was the difference in the initial radium 224 ratios between the two samples. There was a larger concentration of radium 224 in the sample taken from the copper crucible walls than in the sample taken from the furnace shell walls. This difference in concentration may be accounted for by examining the furnace illustrated in figure 2. When volatiles, including radium, are given off during melting, they have a chance to condense along the upper walls of the water-cooled copper crucible before they are exhausted through the furnace shell by the vacuum system. If this occurs, then the crucible walls will naturally have a higher concentration of condensed volatiles than the warmer, more remotely located furnace shell surfaces. 


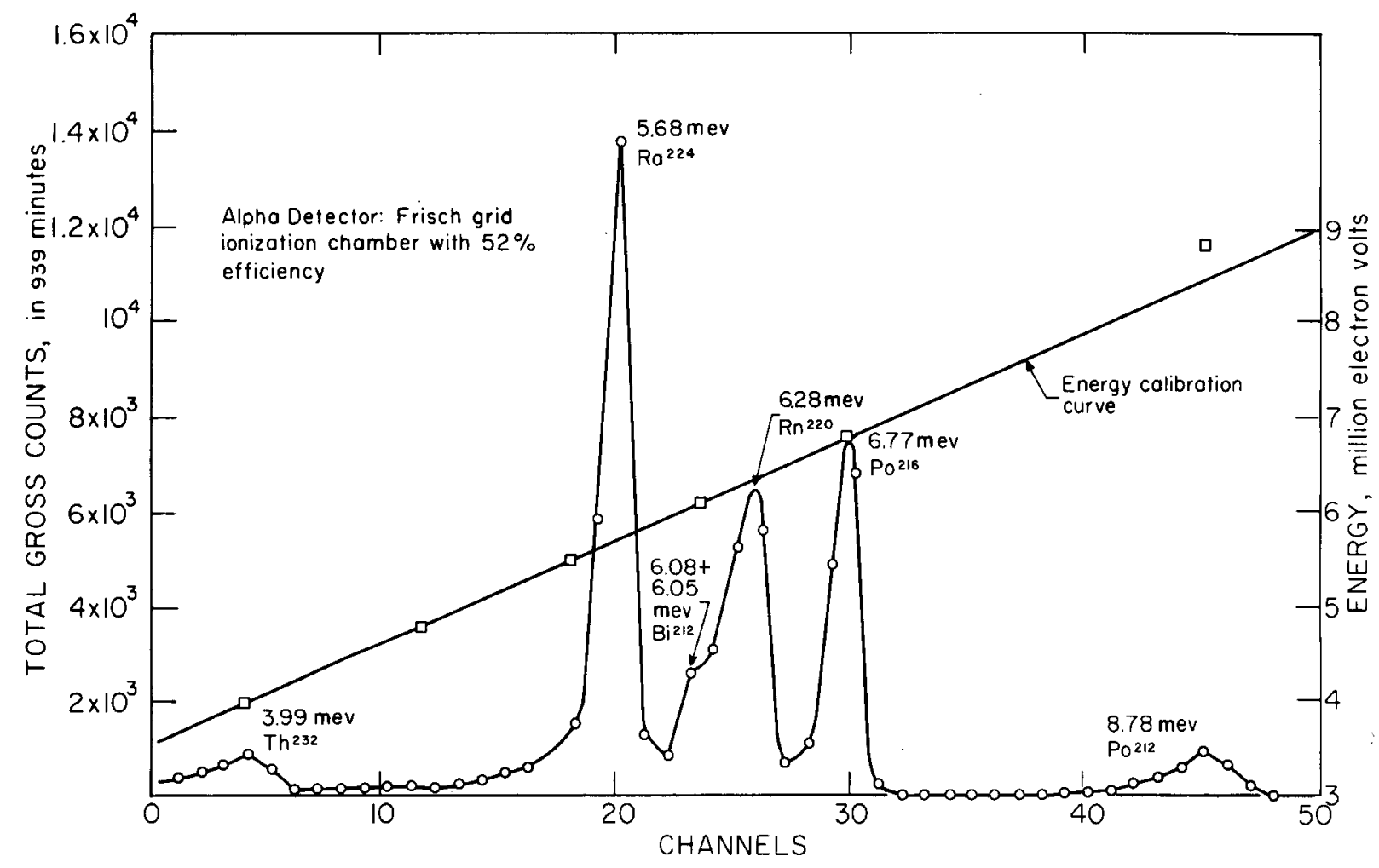

FIGURE 9. - Initial Alpha Spectrum From Crucible Residue.

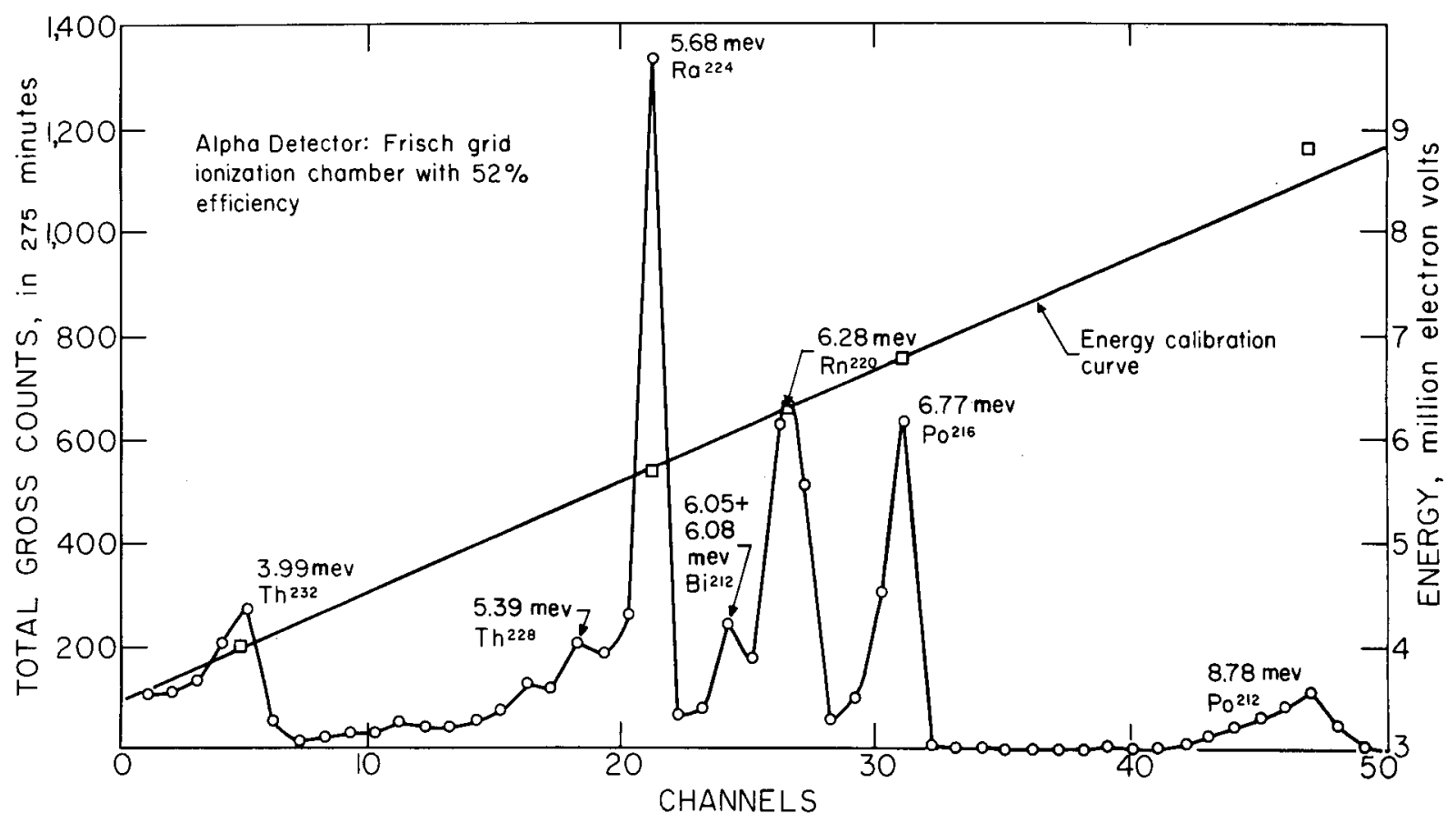

FIGURE 10. - Delayed Alpha Spectrum From Crucible Residue. 
TABLE 3. - Relative isotope activity ratios as taken from figures 7 through 10

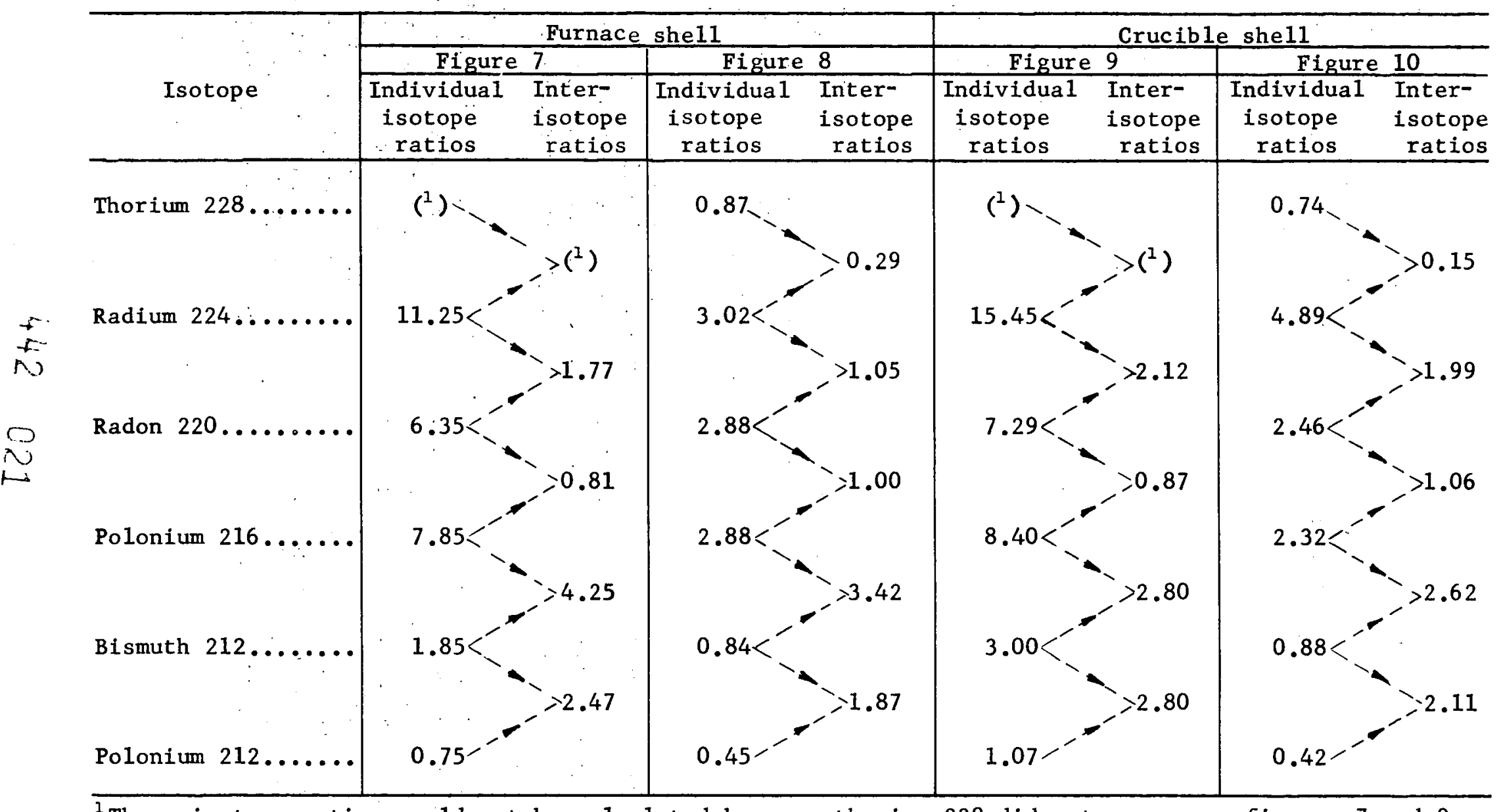

\footnotetext{
${ }^{1}$ These isotope ratios could not be calculated because thorium 228 did not appear on figures 7 and 9 .
} 


\section{Forging Hazards}

The hazard in thorium forging areas arises primarily from the oxides which form on the thorium ingots during preforging heating. These oxides become airborne when they are broken loose from the ingots by such mechanical processes as forging, rolling, swaging, and forming. A group at Rochester, N. Y., has made a study of the chemical toxicity of various thorium compounds, including thorium dioxide (6). These pertinent studies were made upon several animal species.

\section{DISCUSSION}

The work by the Bureau of Mines at the Albany Metallurgy Research Center may or may not be representative of the situation in all melting, machining, and forging operations in process today, but it is certain that the experience acquired here should be passed on to private industry and other organizations that may anticipate the formation of thorium melting facilities.

In particular, the separation of radium from thorium in arc melting makes it imperative that all possible precautions be taken to prevent inhalation, ingestion, or other possible fixation of this bone-seeking isotope in the human body.

The first and most important prerequisite to setting up a thorium melting facility is a well organized health physics group to oversee the operations. The duties of such a group can vary over a wide range, but in general they should encompass the following: (1) Keep records of personnel concerned with the work; these records should include periodic physical examination records as well as personnel radiation exposures as determined by monitoring methods and devices; (2) monitor all areas to see that activities in air and water remain as low as possible and especially do not exceed maximum permissible concentrations and survey for surface contamination of working areas and equipment; (3) act as advisor to supervisory personnel on any problems they have concerning radiation; and (4) assist supervisory personnel in development of standard operating procedures for the various processes involving radioactive materials.

Secondly, the concerned operations should be carried out in buildings that are suited to radioactive work; that is, structures that can be kept clean with a minimum of effort. Proper exhaust ventilation systems must be integrated into the buildings. These ventilation systems must be fitted with filters that prohibit contamination of the atmosphere around the buildings. All operations that generate dusts, fumes, or volatiles should be enclosed in exhaust hoods to prevent spread of contamination throughout the buildings. In addition to this local exhaust ventilation, there should be secondary exhaust ventilation to prevent a gradual buildup of background activity within the buildings. Resistance to wearing respirators is somewhat natural, and consequently supervisors of a laboratory could be considered negligent if they relied on respirators to keep the intake of toxic dusts to a safe level rather than providing adequate engineering control.

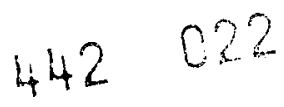


Other precautions that must be stressed in these operational areas are no smoking or eating in working areas and general personal cleanliness habits. In general, all unnecessary activities that would tend to allow ingestion or inhalation of radioactive materials should be prohibited in thorium handling areas. Also, complete clothing changes and showers should be used to prevent carrying radioactive materials outside the working area.

In addition to the conventional precautions necessary in handling radioactive materials, several specific precautions are necessary when arc melting thorium:

1. Arc furnaces should be fitted with exhaustable chambers (see fig. 2) that allow the furnaces to be exhausted and kept at a slightly negative pressure during removal of the ingot and crucible. This feature would prevent the dusts and airborne materials from escaping into the room. Inert gas welding boxes in which small amounts of melting occur, should also be fitted with exhaust systems for the same purpose as the arc furnaces.

2. Ingots should be removed from the crucible in such a manner as to create a minimum of airborne material. A suggested method is in development at the Albany Metallurgy Research Center. The crucible, with the ingot still inside, is fastened to a knockout tube equipped with an exhaust valve connection. The knockout of the ingot is accomplished by inverting and shaking the entire assembly until the ingot comes free from the crucible. An exhaust hose is fastened to the tube and crucible assembly; it picks up the materials that become airborne inside the assembly. After a few minutes, the crucible and tube are separated, and the rough ingot is removed for machining. Figure 11 illustrates the procedure of ingot knockout.

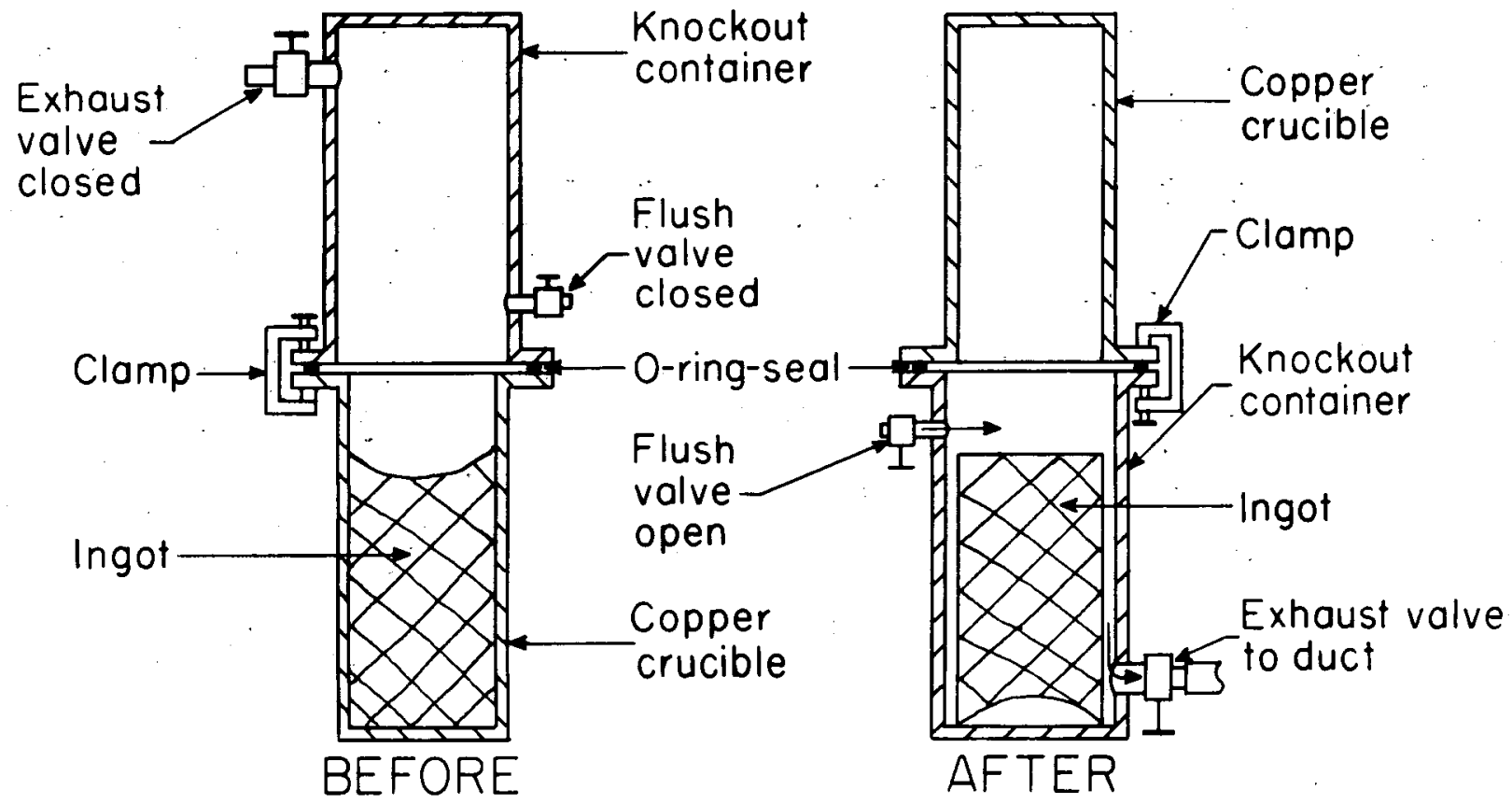

FIGURE 11. - Ingot Knockout Procedure.

$$
442023
$$


3. Machining of ingots should be carried out in a lathe enclosed by a continually exhausting hood. Once the ingot is mounted in the lathe, all lathe adjustments and control operations can be performed from outside the hood.

4. Forging presses, rolling mills, and other fabrication equipment used for thorium working should be fitted with local exhaust hoods and ducts to carry away the airborne oxides and other radioactive dusts and gases.

5. The storage vault for thorium metal and scrap should be provided with a ventilation system to prevent the production of the gaseous isotope, radon 220 , from building up extremely high activity within the vault. In addition to the ventilation system, the thorium storage vault should be remotely located from operating personnel or be well shielded to minimize radiation exposure caused by the gamma emission of thallium 208 .

6. Melting furnace chambers and crucibles are most readily cleaned by acid solutions. The use of acid does present a problem of disposal of the contaminated fluid.

7. Vacuum pumps used for evacuating during thorium arc melts become highly contaminated because of the entrapment of daughters that volatilize during a melt. As shown in table 1 , there is no detectable activity at a pump ${ }^{2} \mathrm{~s}$ exhaust during melting; this is due to the effective filtering action of the mechanical vacuum pump oil. The contaminated oil is not a disposal problem because it can be barrelled for burial as is other waste. It may be necessary, however, to eventually scrap pumps that have been used on thorium melts if they cannot be decontaminated.

8. An item that can easily be overlooked in a laboratory is the exhaust of vacuum cleaners. These exhausts must be filtered just as are other ventilation and exhaust systems.

9. One additional problem connected with thorium is quite important as a radiological hazard. That is, thorium is highly pyrophoric, and any operations that produce thorium fines should be carried out with this fact in mind. This property of thorium, coupled to the fact that arc furnace residues in general are also easily ignited, makes it imperative that furnaces never be opened without face and respiratory protection. Also, in case of a thorium fire, radioactive smoke would spread contamination over a large area. Extinguishing powder (designed to smother metal fires) in extinguishers and barrels should be stationed in all areas where fire hazard exists. 


\section{B IBLIOGRAPHY}

1. ALBERT, R., AND. OTHERS. Industrial Hygiene and Medical Survey of a Thorium Refinery. Industrial Health, vol. 2, March 1955, pP. 234-242.

2. ALLISON, M., MOORE, R, W., RICHARDSON, A. E, , PETERSON; D. T, , AND VOIGT, A. F. Determining Mesothorium Content of Thorium Nitrate. Nucleonics, vol. 12, No. 5, May 1954, pp : 32-34 .

3. COFIELD, R. E. Radioactivity of Thorium and Feasibility of in Vivo Thorium Measurements. AEC Report No. Y-1280, Nov. 11, 1959, 29 pp.

4. CUTHBERT, F. L. Health and Safety Aspects of Thorium Production; ch. in Thorium Production Technology. Addison-Wesley, Reading, Mass., 1958, Pp. 242-254.

5. FRESCO, JAMES, JETTER, EVELYN, AND HARLEY, JOHN. Radiometric Properties of the Thorium Series. Nucleonics, vol. 10, No. 8, August 1952, PP : 60-64.

6. HALL, R. H., STROUD, C. A., SCOTT, J. K., ROOT, R. E., STEADMAN, L. T., AND STOKINGER, H. E. Acute Toxicity of Inhaled Thorium Compounds. The University of Rochester Rpt . No . UR-190, 27," Pp :

7. HEALY, J. W. The Evaluation of Air Samples Containing Thorium and Daughter Products. Hanford Atomic Products Operation, Richland, Wash. Rpt. No. HW(Hanford Works)-35752, March 14, 1955, 19 pp.

8. A Review of the MPC's for Natural Thorium... Hanford Atomic Products Operation, Richland, Wash. Rpt. No. HW-40105, November :21, 1955, 15 pp.

9. HYATT, EDWIN C. Health Hazards Associated with Rolling Normal and Enriched Uranium - Evaluation and Control. Industrial Hygiene Jour., April 1959, pp. 82-91.

10. Maximum Permissible Body Burdens and Maximum Permissible Concentrations of Radionuclides in Air and in Water for Occupational Exposure. U.S.

- Department of Commerce, Nat. Bureau of Standards Handbook No. 69, pp. 82-82.

11. MAYS, C. W., HALDIN, R., AND VAN DILLA, M. A. Thoron Exhalation in Radiothorium Burdened Beagles. Radiation Res., vol. 9, 1958, pp. 438-444.

12. PETERSON, D. T., MOORE, R. W., AND ALLISON, M. Separation of Ra ${ }^{2 a 8}$ in Thorium Metal Production. Ames Laboratory, Iowa State College Report No. ISC-425, pp. 3-5.

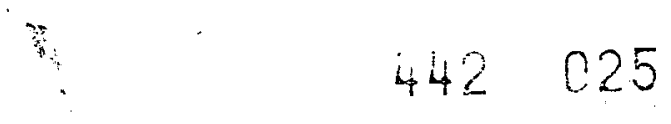


13. Radium and Mesothorium Poisoning and Dosimetry and Instrumentation Techniques in Applied Radioactivity. Annual Prog. Rpt., Radioactivity Center, Massachusetts Institute of Technology, AECU-4285, May, 1959, $161 \mathrm{pp}$.

14. ROBERSON, A. H., AND BEALL, R. A. Consumable Electrode Arc Melting of Thorium: Chapter in the Metal Thorium. A.S.M. and A.E.C. Symposium on Thorium, Cleveland, Ohio, copyright 1958, 397 pp.

15. SNYDER, W. S. Range of Uncertainty of MPC Values; Selected Materials on Radiation Protection Criteria and Standards: Their Basis and Use. Joint Committee on Atomic Energy-86th Congress of United States, 2d Session, May 1960, pp. 374-381.

16. STOVER, B. J., ATHERTON, D. R., KELLER, N., AND BUSTER, D. S. Metabolism of the $\mathrm{Th}^{2 a}$ Decay Series in Adult Beagle Dogs. Radiation Res., vol. 12, 1960, pp. 657-671.

17. VAN DILLA, M. A., AND STOVER, B. J. On the Role of Radiothorium ( $\mathrm{Th}^{228}$ ) in Radium Poisoning. Radiology, vo1. 66, No. 3, March 1956, pp. 400-401.:

18. VAN DILIA, M. A., STOVER, B. J., AND ARNOLD, J. S。 On the Retention and Translocation of $\mathrm{Ra}^{224}$ ( $\mathrm{Th} \mathrm{X}$ ) in Dogs. The American Jour. of Roentgenology, Radium Therapy and Nuclear Medicine, vo1. 77, No. 3, March 1957, Pp. 503-510.

19. VOHRA, K. G. A New Method for the Estimation of Radon and Thoron Contamination in Air and Its Applications. Proc. 2d United Nations International Conference on the Peaceful Uses of Atomic Energy, United Nations, Geneva, vo1. 23, 1958, pp. 367-371. 